\title{
The Use of Ascorbic Acid to Promote the Polymerization of 11S Globulin
}

\author{
Kimio Nishimura ${ }^{1 *}$, Sayaka IkeuchI ${ }^{1,2}$ and Yuka Miүaмото ${ }^{3}$ \\ ${ }^{1}$ Department of Food Science and Nutrition, Doshisha Women's College of Liberal Arts, Kamigyo-ku, Kyoto 602-0893, Japan \\ ${ }^{2}$ Ibaragiya Co. Ltd., 39 Toraishi, Nakagyo-ku, Kyoto 604-0955, Japan \\ ${ }^{3}$ Department of Home Economics, Shukugawa Gakuin College, 6-58 Koshikiiwa-cho, Nishinomiya 662-8555, Japan
}

Received May 27, 2007; Accepted November 14, 2007

We investigated the effects of L-ascorbic acid (AsA) on $11 \mathrm{~S}$ globulin, which was reduced by 2-mercaptoethanol. Sodium dodecyl sulfate-polyacrylamide gel electrophoresis analysis verified that AsA promoted the polymerization of $11 \mathrm{~S}$ globulin via the formation of disulfide bridges. The generation of thiyl radicals (S·) in $11 \mathrm{~S}$ globulin was examined by electron spin resonance spectroscopy coupled with spin trapping. The superoxide anion radical $\left(\mathrm{O}_{2}^{-}\right)$was produced by the photoactivation of riboflavin. A typical line shape was observed for $\mathrm{S} \cdot$. Staining with nitroblue tetrazolium dye confirmed that $\mathrm{O}_{2}^{-}$was produced in the $11 \mathrm{~S}$ globulin solution due to the autooxidation of AsA. Although the 11S globulin lacking AsA did not yield a rigid gel, the sample containing AsA successfully yielded a rigid gel. Thus, it is clear that $\mathrm{O}_{2}^{-}$generated during AsA oxidation exerts beneficial effects on 11S globulin in its reduced form.

Keywords: vitamin C, polymerization, 11S globulin, superoxide anion radical, electron spin resonance (ESR), thiyl radical, disulfide (SS) bridges

\section{Introduction}

In several studies (Sarwin et al., 1993; Hahn and Gosch, 1998; Grosch and Wiesre, 1999; Koehler, 2003), which we have described in previous papers (Miyamoto and Nishimura, 2006a, 2006b), the beneficial effects that L-ascorbic acid (AsA) exerts on bread have been represented by the scheme shown in Fig. 1-A (Kuninori and Nishiyama, 1993). The mechanism by which AsA improves the quality of heat-induced fish gel (kamaboko) is considered to be as represented in Fig. 1-A, since the addition of dehydro-L-ascorbic acid (DHA) to raw fish paste (surimi) increases the strength of heat-induced fish gel (kamaboko) (Yoshinaka et al., 1972). However, based on the results obtained in a series of previous studies (Nishimura et al., 1992a, 1992b, 1994, 1996; Miyamoto and Nishimura, 2006a), Nishimura et al. clarified that the beneficial effects exerted by AsA on heat-induced fish gel (kamaboko) were due to a different mechanism involving the superoxide anion radical $\left(\mathrm{O}_{2}^{-}\right)$, shown in Fig. 1-B (Nishimura et al., 1996; Miyamoto and Nishimura, 2006a) and that AsA acted more readily on the subfragment-1 region of myosin (Ikeuchi et al., 2007). Furthermore, Miyamoto

*To whom correspondence should be addressed.

Email: knishimu@dwc.doshisha.ac.jp and Nishimura (2006b) observed that $\mathrm{O}_{2}^{-}$promotes polymerization among peptides derived from wheat proteins via the formation of disulfide (SS) bridges, in keeping with the mechanism shown in Fig. 1-B. This suggests that AsA may exert beneficial effects for not only on myosin but also on other food proteins in the manner indicated in Fig. 1-B.

Soy protein, the most popular plant protein source to serve as an ingredient in the food industry, is not a homogeneous protein. The major protein fractions in soybean are 2S, $7 \mathrm{~S}, 11 \mathrm{~S}$, and $15 \mathrm{~S}$ globulins, of which $7 \mathrm{~S}$ and $11 \mathrm{~S}$ globulins are able to form intermolecular SS bonds, leading to protein insolubility and increased turbidity and viscosity of its solution (Briggs and Wolf, 1957; Circle et al., 1964; Nash and Wolf, 1967). Yamauchi (1980, 1982), Kilara and Harwalkar (1996), and Morita (2000) conducted a number of studies related to the process of gel formation by heat treatment, and the important role played by intermolecular SS bonds in gel formation has been previously elucidated. In particular, $11 \mathrm{~S}$ globulin is known to be involved in formation of polymers containing sulfhydryl (SH) groups (Wolf and Tamura, 1969; Wolf, 1976). Because the amount of cysteine in protein molecule is higher in 11S than 7S globulin (Koshiyama, 1968; Catsimpoolas et al., 1971), and SH groups in 11S globulin are more reactive than those in $7 \mathrm{~S}$ globulin (Saio et al., 
A

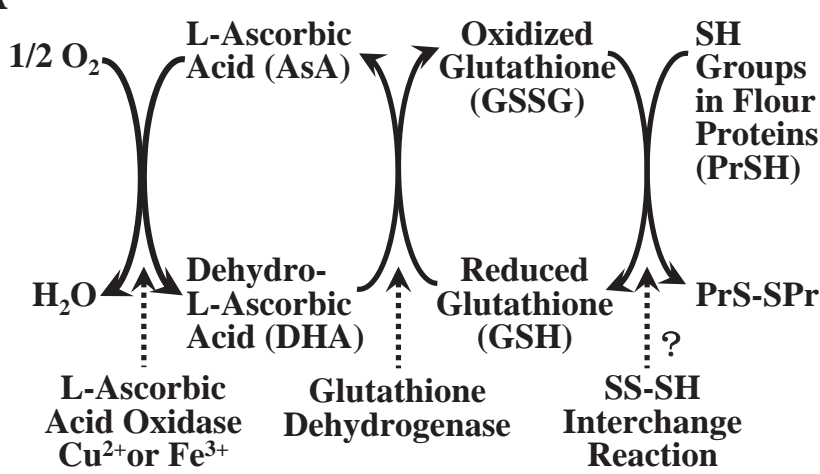

B

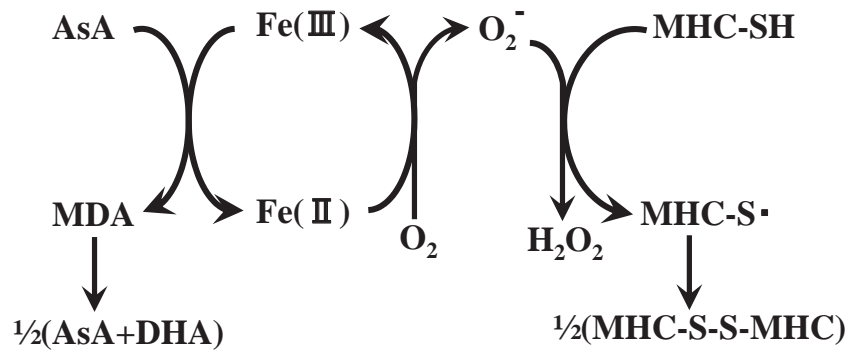

Fig. 1. Schematic representation of dough improvement using L-ascorbic acid (AsA) (Kuninori and Nishiyama, 1993) (A) and scheme for $\mathrm{O}_{2}^{-}$-dependent polymerization of the myosin heavy chain (MHC) (Nishimura et al., 1996; Miyamoto and Nishimura, 2006a) (B). AsA in dough is oxidized to dehydro-L-ascorbic acid (DHA) by L-ascorbic acid oxidase or transition metals(A). Further, reduction of DHA to AsA by glutathione dehydrogenase in turn results in the oxidation of reduced glutathione. This oxidation promotes the formation of disulfide (SS) bridges among the proteins flour via SSsulfhydryl (SH) exchange. Fe(II) is shown as an example of a trace metal ion that catalyzes the autooxidation of AsA (B). Monodehydro-L-ascorbic acid (AsA radical) (MDA), the univalently oxidized product of AsA, is spontaneously disproportionated to AsA and DHA. Fe(II) reduces molecular oxygen, forming $\mathrm{O}_{2}^{-}$. $\mathrm{O}_{2}^{-}$then removes hydrogen radicals from $\mathrm{SH}$ groups on $\mathrm{MHC}$, thus generating thiyl radical (S-); 2 molecules of S. can then combine to form an SS bond.

1971). In this study, we aimed to prove that AsA can accelerate the gel formation of $11 \mathrm{~S}$ globulin in the manner shown in Fig. 1-B.

\section{Materials and Methods}

Materials and Chemicals The powder of 11S globulin was supplied by Fuji Oil Co. Ltd. (Osaka, Japan) and stored at $-4^{\circ} \mathrm{C}$ until use. Reagent-grade $N$-ethylmaleimide (NEM) and biochemical grade superoxide dismutase (SOD) extracted from bovine erythrocytes, and catalase extracted from bovine liver were obtained from Wako Pure Chemicals (Osaka, Japan); 5,5-dimethyl-1-pyrroline- $N$-oxide (DMPO; 99.5\% purity) was obtained from Labotec (Tokyo, Japan). The other chemicals used were of reagent grade and were obtained from Nacalai Tesque (Kyoto, Japan).

Preparation of several different $11 S$ globulin samples We dissolved $1.5 \mathrm{~g}$ of $11 \mathrm{~S}$ globulin powder in $30 \mathrm{ml}$ of 20 $\mathrm{mM}$ phosphate buffer ( $\mathrm{pH} 7.0$ ) containing $5 \mathrm{M}$ guanidine hydrochloride and $0.3 \mathrm{M} \mathrm{NaCl}$; the mixture was stirred overnight until all the 11S globulin dissolved. To a part of the buffer, 1\% 2-mercapthoethanol was added, and the solution was stirred. Both solutions were dialyzed for $20 \mathrm{~h}$ against 20 $\mathrm{mM}$ phosphate buffer ( $\mathrm{pH} 7.0$ ) containing $0.3 \mathrm{M} \mathrm{NaCl}$. The dialytic fluid unaffected by 2-mercaptoethnol was designated the nonreduced 11S globulin solution, and the dialytic fluid reduced by 2-mercaptoethnol was designated the reduced $11 \mathrm{~S}$ globulin solution. Both solutions were concentrated to approximately twice their original concentrations using polyethylene glycol, which absorbs water. The concentrate unaffected by 2-mercaptoethnol was designated the nonreduced $11 \mathrm{~S}$ globulin concentrate and the concentrate reduced by 2-mercaptoethnol was designated the reduced $11 \mathrm{~S}$ globulin concentrate. All of these steps were carried out at $4^{\circ} \mathrm{C}$.

Sodium dodecyl sulfate (SDS)-polyacrylamide gel electrophoresis (PAGE) analysis Ten microliters of $20 \mathrm{mM}$ phosphate buffer (pH 7.0) containing $0.3 \mathrm{M} \mathrm{NaCl}$ and containing or lacking $20 \%$ AsA was added to $990 \mu \mathrm{l}$ of the reduced 11S globulin solution; each mixture was heated at 80 ${ }^{\circ} \mathrm{C}$. Following heat treatment for 15, 30, 60 and $120 \mathrm{~min}, 3$ times the volume of $0.125 \mathrm{M}$ Tris-HCl buffer (pH 6.8) containing $4 \%$ SDS and $20 \%$ glycerol was added to each sample. Next, 2-mercaptoethanol was added to a part of each reduced $11 \mathrm{~S}$ globulin sample to attain a final concentration of $10 \%$, and the mixtures obtained were heated at $100^{\circ} \mathrm{C}$ for $3 \mathrm{~min}$; SDS-PAGE was performed at $20 \mathrm{~mA}$ for approximately $1 \mathrm{~h}$, as described by Laemmli (1970).

Densitometric measurements The high molecular weight aggregates, which could not enter the stacking gel in the SDS-PAGE performed using the reduced 11S globulin samples, were quantified at $640 \mathrm{~nm}$ using a densitometer (Shimadzu CS-9000 dual-wavelength flying spot scanner; Shimadzu Co., Kyoto, Japan).

Protein quantification The protein content of the nonreduced and reduced 11S globulin solutions and concentrates was determined using the method of Lowry (1951).

Measurement of the SH content We dissolved $100 \mu \mathrm{l}$ each of the nonreduced and reduced 11S globulin concentrates in $19.9 \mathrm{ml}$ of $0.1 \mathrm{M}$ Tris-HCl buffer (pH 8.0) containing $6 \mathrm{M}$ guanidine hydrochloride and $0.01 \mathrm{M}$ ethylenediamine tetraacetic acid. The SH content was determined according to the method of Ellman (1959). As a control, the respective solution sample and concentrate sample without $11 \mathrm{~S}$ globulin were also prepared through the same manner represented in "preparation of several different 11S globulin 
samples”, and it was confirmed that they did not affect the measurement of protein quantification and the SH content.

Sample preparation for electron spin resonance (ESR) spectroscopy Electron spin resonance spectroscopy was performed for $11 \mathrm{~S}$ globulin using solutions that contained either the nonreduced or the reduced $11 \mathrm{~S}$ globulin concentrate. These solutions contained $73.5 \pm 1.4 \mathrm{mg} / \mathrm{ml}(\mathrm{n}=3)$ of protein. To determine the effect of SOD and catalase on reduced $11 \mathrm{~S}$ globulin, we added SOD (100 units $(\mathrm{u}) / \mathrm{ml})$ or catalase $(1,200 \mathrm{u} / \mathrm{ml})$, or an equivalent amount of heat-inactivated SOD or catalase, to reduced $11 \mathrm{~S}$ globulin samples. All the samples also contained $1 \mathrm{mM}$ diethylenetriaminepentaacetic acid, $0.5 \mu \mathrm{M}$ riboflavin, $75 \mathrm{mM}$ DMPO (as a spin-trapping reagent), and $25 \mathrm{mM}$ piperazine-1,4-bis(2-ethanesulfonic acid) (PIPES) buffer (pH 7.0). Heat-inactivated SOD and catalase were produced by heating 10,000 or $120,000 \mathrm{u} / \mathrm{ml}$ of the respective enzymes at $110^{\circ} \mathrm{C}$ overnight under vacuum.

ESR spectroscopy Electron spin resonance spectroscopy was carried out using an X-band ESR spectrometer (JES-FA 100; Jeol Ltd., Tokyo, Japan) with 100-KHz field modulation at room temperature in a $0.04-\mathrm{mm}$ flat cell (RDC-60-S; Radical Research Inc., Tokyo, Japan). White actinic light (325,000 lx) emitted by a halogen lamp (Mega Light 100; Hoya-Schott, Tokyo, Japan) was used for flavin excitation. Following illumination for 4 min, the ESR spectra were recorded under the following conditions: center field, 327.2 $\mathrm{mT}$; microwave power, $16 \mathrm{~mW}$; modulation width, $0.1 \mathrm{mT}$; amplitude, 2000; sweep time, 4 min; and time constant, $0.3 \mathrm{~s}$. The magnetic field strength and apparent signal intensity of the thiyl radical (S·) adduct were calibrated based on the ESR signals obtained using Mn (II)-doped MgO powder.

Presence of $\mathrm{O}_{2}^{-}$in the reduced $11 \mathrm{~S}$ globulin concentrate containing AsA To $850 \mu \mathrm{l}$ of the reduced 11S globulin concentrate, $50 \mu \mathrm{l}$ of $20 \mathrm{mM}$ phosphate buffer (pH 7.0) containing $10 \mathrm{mM}$ nitroblue tetrazolium (NBT) and $0.3 \mathrm{M} \mathrm{NaCl}$ and $100 \mu \mathrm{l}$ buffer containing only $0.3 \mathrm{M} \mathrm{NaCl}$ were added to obtain the control mixture for $\mathrm{O}_{2}^{-}$estimation. To obtain the AsA mixture, to $850 \mu \mathrm{l}$ of the reduced $11 \mathrm{~S}$ globulin concentrate, $50 \mu \mathrm{l}$ buffer containing $0.2 \% \mathrm{AsA}$ and $0.3 \mathrm{M} \mathrm{NaCl}$, and $50 \mu \mathrm{l}$ buffer containing only $0.3 \mathrm{M} \mathrm{NaCl}$ were added instead of $100 \mu$ l buffer containing $0.3 \mathrm{M} \mathrm{NaCl}$. Further, to obtain the 1,2-dihydroxybenzene-3,5-disulfonic acid disodium salt (Tiron) mixture, $50 \mu \mathrm{l}$ buffer containing $0.3 \mathrm{M} \mathrm{NaCl}$ and 400 $\mathrm{mM}$ Tiron, which was used as an $\mathrm{O}_{2}^{-}$scavenger, was added instead of $50 \mu$ l buffer containing $0.3 \mathrm{M} \mathrm{NaCl}$. The final concentrations of the NBT, AsA, and Tiron mixtures were $0.5 \mathrm{mM}, 0.01 \%$, and $20 \mathrm{mM}$, respectively. Each mixture was incubated at $80^{\circ} \mathrm{C}$ for $1 \mathrm{~min}$, and the color change was observed as an indicator of NBT reduction by $\mathrm{O}_{2}^{-}$.

Influence of AsA on the heat-mediated gelation of the reduced $11 S$ globulin concentrate To $980 \mu \mathrm{l}$ of the reduced 11S globulin concentrate, $20 \mu \mathrm{l}$ of $20 \mathrm{mM}$ phosphate buffer (pH 7.0) containing 25.0\% AsA and $0.3 \mathrm{M} \mathrm{NaCl}$ was added to obtain the AsA mixture for gelation, while only $20 \mu$ l buffer containing $0.3 \mathrm{M} \mathrm{NaCl}$ was added to obtain the control sample. Both mixtures containing $75.4 \pm 1.5(\mathrm{n}=3) \mathrm{mg} / \mathrm{ml}$ of protein were incubated at $80^{\circ} \mathrm{C}$ for $20 \mathrm{~min}$, and a state wherein the contents spilled over the sides of the test tube was observed on cooling with ice water.

\section{Results and Discussion}

Promotive effects of AsA on SS bridging in reduced 11S globulin Saio et al. (1974) reported that a temperature of $90^{\circ} \mathrm{C}$ is necessary to induce gel formation in $11 \mathrm{~S}$ globulin fractions; however, the reduced $11 \mathrm{~S}$ globulin used in this study contained more thiol groups than the native fraction, and could easily form a gel when heated. Therefore, we selected $80^{\circ} \mathrm{C}$ as the heating temperature and investigated the effects of AsA on reduced 11S globulin solution (protein content, $44.1 \pm 0.7 \mathrm{mg} / \mathrm{ml}(\mathrm{n}=3)$; $\mathrm{SH}$ group content, 2.5 $\pm 0.1 \mu \mathrm{mol} / \mathrm{ml}(\mathrm{n}=3)$ ) by SDS-PAGE analysis (Fig. 2). A major change that occurred in the reduced $11 \mathrm{~S}$ globulin solution lacking AsA when heated at $80^{\circ} \mathrm{C}$ was the appearance of high molecular weight aggregates that could not enter the stacking gel; further, the content of basic subunits decreased on heating for 120 min (Fig. 2, lane E). The content of acidic subunits also appeared to decrease slightly. In the case of the reduced 11S globulin solution containing AsA (Fig. 2, lanes F-I), high molecular weight aggregates appeared early during heat treatment and could be observed after $30 \mathrm{~min}$ (Fig. 2, lanes G-I). These high molecular weight aggregates were formed due to polymerization via SS bridging since the acidic and basic subunit content was increased on adding

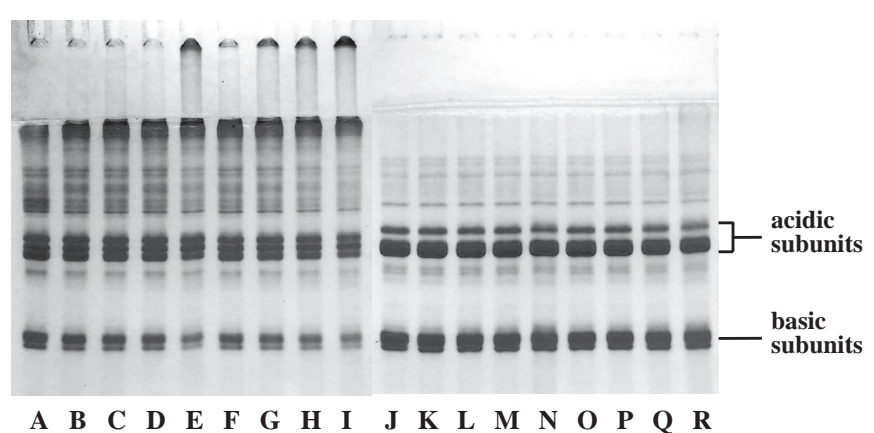

Fig. 2. Influence of AsA on changes occurring in reduced 11S globulin when heated at $80^{\circ} \mathrm{C}$. The reduced $11 \mathrm{~S}$ globulin solution lacking AsA (lane A) was heated at $80^{\circ} \mathrm{C}$ for 15 (lane B), 30 (lane C), 60 (lane D), and 120 min (lane E). Similarly, the reduced 11S globulin solution containing $0.2 \%$ AsA was also heated at $80^{\circ} \mathrm{C}$ for 15 (lane F), 30 (lane G), 60 (lane H) and 120 min (lane I). Lanes $\mathrm{J}$-R represent the profiles obtained on adding 2-mercaptoethanol to lanes A-I to a final concentration of $10 \%$. 


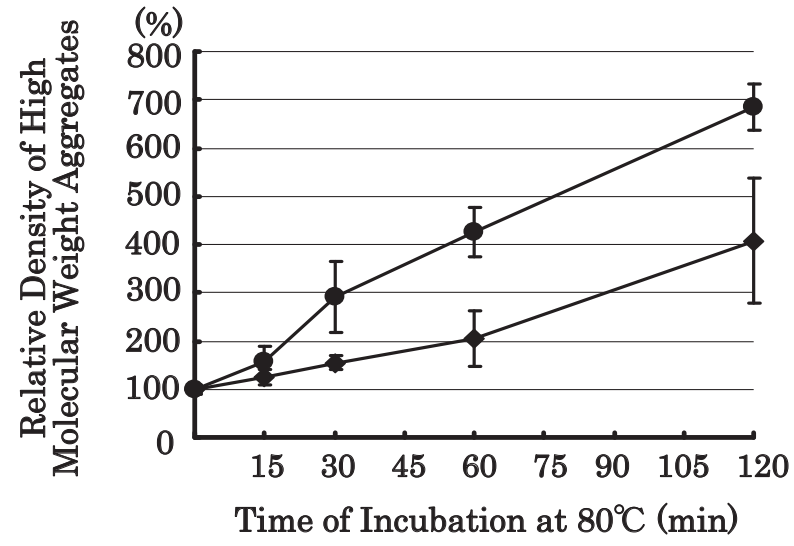

Fig. 3. Influence of AsA on the formation of high molecular weight aggregates on heat treatment at $80^{\circ} \mathrm{C}$. The densities of the high molecular weight aggregates obtained in the absence $(\bullet)$ or presence (๑) of $0.2 \%$ AsA were determined by measuring the SDS-PAGE patterns in lanes A-I, as shown in Fig. 2, using a densitometer. The density of the high molecular weight aggregates in the unheated sample (lane A in Fig. 2) was regarded as 100\%.

2-mercaptoethanol (Fig. 2, lanes $\mathrm{N}$ and P-R). The changes in the amounts of high molecular weight aggregates present were analyzed densitometrically and assessed in relation to the amounts present immediately prior to heating (Fig. 3). In the reduced 11S globulin solution lacking AsA, the amount of high molecular weight aggregates increased to approximately 2 and 4 times the original following heat treatment for 60 and $120 \mathrm{~min}$, respectively. However, for the solution containing AsA, the amount of high molecular weight aggregate present increased to approximately 3, 4 and 7 times the original following heat treatment for 30, 60 and $120 \mathrm{~min}$, respectively. Although accurate quantity of high molecular weight aggregates could not determined with densitometric measurements because of the measuring adherent amount of them to stacking gel, the dense of those band was considered to reflect quantity of high molecular weight aggregates. Accordingly, it was clarified that formation of high molecular weight aggregates was increased by addition of AsA. These results above suggested that AsA functioned to promote the formation of SS bridges on heat treatment at $80^{\circ} \mathrm{C}$ (Fig. 2).

Next, we investigated whether this AsA-mediated increase in polymerization was consistent with the schematic representation in either Fig. 1-A or 1-B. Saio et al. (1974) reported that the gelation of $7 \mathrm{~S}$ and $11 \mathrm{~S}$ globulin needed a high temperature over $80^{\circ} \mathrm{C}$, suggesting that it was difficult to consider such mechanism involving enzymes as indicated in Fig. 1-A. Since, enzymes were denatured and inactivated under a high temperature. Accordingly, under such a high temperature, we can consider that this AsA-mediated increase in polymerization was consistent with the schematic representation in Fig. 1-B, not Fig. 1-A. If consistent with the representation in Fig. 1-B, we would be able to detect the generation of $\mathrm{S} \cdot$ in reduced $11 \mathrm{~S}$ globulin by $\mathrm{O}_{2}^{-}$based on the ESR analysis.

Estimation of the SH content in the 11S globulin concentrates for ESR spectroscopy The SH content of the nonreduced and reduced $11 \mathrm{~S}$ globulin concentrates was 0.2 $\pm 0.2(\mathrm{n}=3)$ and $4.9 \pm 0.1(\mathrm{n}=3) \mu \mathrm{mol} / \mathrm{ml}$, respectively. The protein content of both concentrates was $88.2 \pm 0.17$ $\mathrm{mg} / \mathrm{ml}(\mathrm{n}=3)$. Since the molecular weight of $11 \mathrm{~S}$ globulin is known to be 302,000-375,000 (Badley et al., 1975; Kitamura et al., 1976; Utsumi et al., 1981), the SH content per molecule of the reduced $11 \mathrm{~S}$ protein was considered to be approximately 17-21. Further, molecule of $11 \mathrm{~S}$ globulin is reported to contain 2 free thiol groups and approximately 20 SS bonds (Yamauchi, 1980, 1982); thus, approximately half of the total number of SS bridges were reduced to SH groups in the reduced $11 \mathrm{~S}$ globulin. Since the samples for ESR spectroscopy were derived from these concentrates and diluted to 1.2 times, the SH content per milliliter of the nonreduced and reduced 11S globulin samples was $0.2 \pm 0.1(\mathrm{n}=3)$ and 4.1 $\pm 0.1 \mu \mathrm{mol}(\mathrm{n}=3)$, respectively.

Detection of radicals in $11 S$ globulin by ESR spectroscopy coupled with DMPO spin trapping In the ESR spectroscopic analysis of AsA, we could not detect S., because only monodehydro-L-ascorobic acid (AsA radical) was detected due to its persistence. Therefore, we used photoactivated riboflavin as an $\mathrm{O}_{2}^{-}$source (Nishimura et al., 1996; Miyamoto and Nishimura, 2005, 2006a, 2006b) for the ESR measurements.

Prior to illumination with white light (325,000 lx), no ESR signals could be detected in the reduced 11S globulin sample (Fig. 4-A). However, following illumination for 4 min, quartet splitting was detected with a signal intensity ratio of 1:2:2:1 (Fig. 4-B). The obtained signal was similar to the characteristic line shape obtained for S in cysteine (Nishimura et al., 1996) and glutathione (Miyamoto and Nishimura, 2006a). For the sample that contained nonreduced 11S globulin, we obtained a weaker ESR spectrum following illumination (Fig. 4-C). These findings strongly suggest that the signal obtained, as shown in Fig. 4-B, was yielded by $\mathrm{S}$.

To determine the type of radical species responsible for the generation of $\mathrm{S}$. in reduced $11 \mathrm{~S}$ globulin, we examined the effectiveness of SOD $(100 \mathrm{u} / \mathrm{ml})$ as an $\mathrm{O}_{2}^{-}$scavenger. Further, we examined the effectiveness of an equivalent amount of heat-inactivated SOD as all proteins are known to have some radical scavenging activity (Davies 1987; Soriani et al. 1994; Halliwell and Gutteridge 1999). As shown in Fig. 4-D, the ESR signal obtained for the reduced 11S globulin sample containing SOD was very weak. In contrast, by adding heat- 


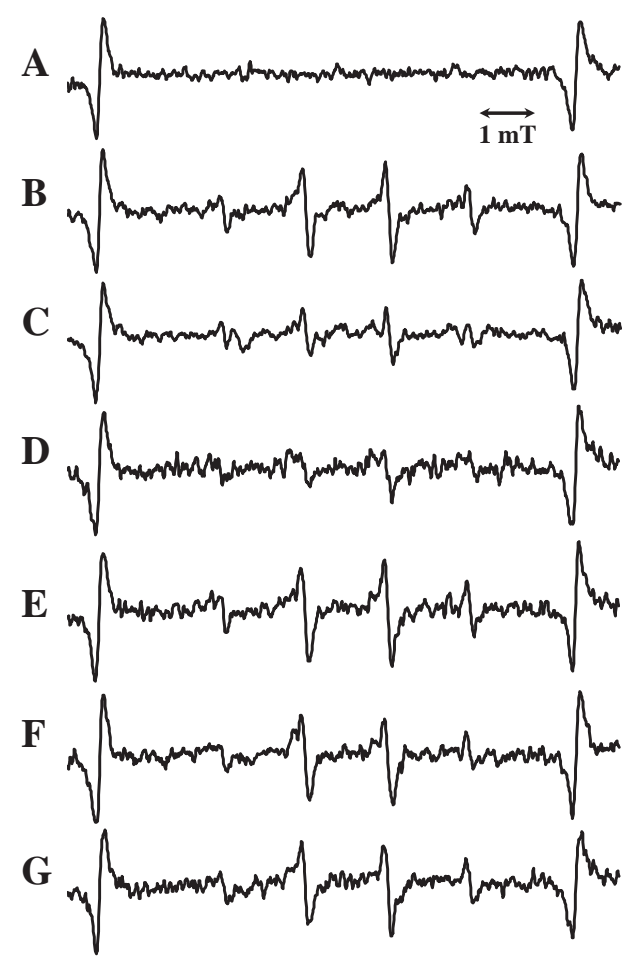

Fig. 4. Detection of $S \cdot$ in $11 S$ globulin by electron spin resonance (ESR) spectroscopy coupled with 5, 5-dimethyl-1-pyrroline- $N$ oxide (DMPO) spin trapping. Electron spin resonance spectroscopic analysis of $11 \mathrm{~S}$ globulin was performed using solutions containing the nonreduced or reduced $11 \mathrm{~S}$ globulin concentrate, $1 \mathrm{mM}$ diethylenetriaminepentaacetic acid, $0.5 \mu \mathrm{M}$ riboflavin, $75 \mathrm{mM}$ DMPO, and 25 mM PIPES buffer ( $\mathrm{pH} 7.0$ ) containing $0.3 \mathrm{M} \mathrm{NaCl}$. This ESR sample contained $73.5 \pm 1.4 \mathrm{mg} / \mathrm{ml}(\mathrm{n}=3)$ of protein. The sample containing the reduced $11 \mathrm{~S}$ globulin concentrate was incubated at room temperature in the dark (A) or for 4 min under white light illumination at 325,000 lx (B) and then examined by spin-trapping ESR spectroscopy. Traces C-E were recorded under the same conditions as those used for trace B, except that the nonreduced 11S globulin concentrate replaced the reduced concentrate in $\mathrm{C}$, and SOD $(100 \mathrm{u} / \mathrm{ml})$ and an equivalent amount of heat-inactivated SOD were added in D and E, respectively. Traces F and $\mathrm{G}$ were recorded under the same conditions as those used for trace B, except that catalase $(1,200 \mathrm{u} / \mathrm{ml})$ and an equivalent amount of heat-inactivated catalase were added in F and G, respectively.

inactivated SOD to the reduced 11 S globulin (Fig. 4-E), the line shape and signal intensity obtained were similar to those for the control lacking the enzyme (Fig. 4-B). Similarly, by adding catalase $(1,200 \mathrm{u} / \mathrm{ml})$ to determine the role played by hydrogen peroxide $\left(\mathrm{H}_{2} \mathrm{O}_{2}\right)$ (Fig. 4-F) or an equivalent amount of heat-inactivated catalase (Fig. 4-G), the line shape and signal intensity obtained were similar to those obtained for the control lacking the enzyme (Fig. 4-B).

Further, we calculated the signal intensity of each second main peak in relation to that yielded by the control (Fig. $4-B)$. When the mean of the signal intensity in the control sample was regarded as $100.0 \%$, the values obtained for the nonreduced $11 \mathrm{~S}$ globulin sample and the reduced $11 \mathrm{~S}$ globu- lin samples containing SOD $(100 \mathrm{u} / \mathrm{ml})$ were about 50 and $40 \%$, respectively. The values obtained for the other samples were mostly similar to the control. These results suggest that the decrease observed in signal intensity, as shown in Fig. 4-D, was due to the elimination of $\mathrm{O}_{2}^{-}$, not $\mathrm{H}_{2} \mathrm{O}_{2}$, and that $\mathrm{O}_{2}^{-}$is responsible for the generation of $\mathrm{S}$. in the reduced $11 \mathrm{~S}$ globulin.

When AsA exerts beneficial effects on heat-induced fish gel (kamaboko) according to the mechanism shown in Fig. 1-B, the generation of $S$ - in muscle protein was anticipated (Miyamoto and Nishimura, 2006a). Further, based on the report by Miyamoto and Nishimura (2006b) regarding the generation of $\mathrm{S}$. by $\mathrm{O}_{2}^{-}$in wheat peptides, we could probably use AsA to improve the quality of bread via the mechanism shown in Fig. 1-B in combination with that shown in Fig. 1-A. In this study, we observed the generation of $\mathrm{S} \cdot$ by $\mathrm{O}_{2}^{-}$ in reduced $11 \mathrm{~S}$ globulin. Our observations indicate that AsA possibly exerts beneficial effects on $11 \mathrm{~S}$ globulin via the mechanism shown in Fig. 1-B. The possibility that beneficial effect of AsA on soy proteins was carried out according to the way shown in Fig. 1-A was not denied completely. However, the gelation of 7S and 11S globulin need high temperature over $80^{\circ} \mathrm{C}$ (Saio et al., 1974). Accordingly, it is difficult to consider the mechanism involving enzymes represented in Fig.1-A, because of thermal denaturation of enzymes. However, since riboflavin instead of AsA was used as an $\mathrm{O}_{2}^{-}$ source in the ESR spectroscopy, it was unclear whether $\mathrm{O}_{2}^{-}$ was generated due to the oxidation of AsA in the reduced 11S globulin concentrate. Therefore, we investigated this point further.

Detection of $\mathrm{O}_{2}^{-}$generated due to the oxidation of AsA in the reduced $11 S$ globulin concentrate The control mixture for $\mathrm{O}_{2}^{-}$estimation (Fig. 5-A), the AsA mixture (Fig. 5-B), and the Tiron mixture (Fig. 5-C) were prepared and subsequently then heated at $80^{\circ} \mathrm{C}$ for $1 \mathrm{~min}$. The production of $\mathrm{O}_{2}^{-}$

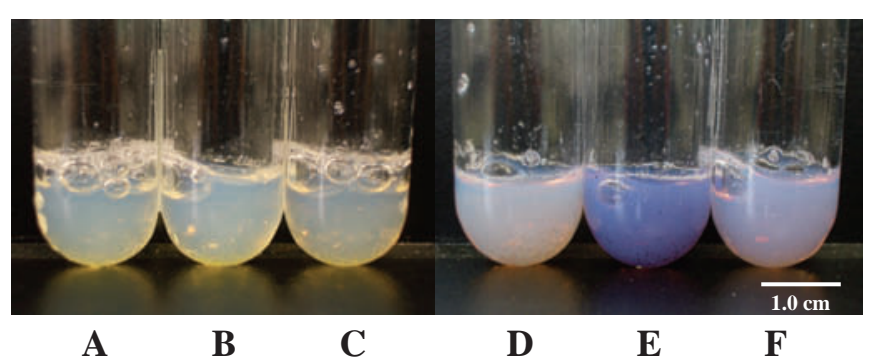

Fig. 5. Presence of $\mathrm{O}_{2}^{-}$in the AsA-containing reduced $11 \mathrm{~S}$ globulin concentrate before and after heat treatment at $80^{\circ} \mathrm{C}$. The reduced $11 \mathrm{~S}$ globulin concentrate containing $0.5 \mathrm{mM}$ NBT (control mixture for $\mathrm{O}_{2}^{-}$estimation; A), $0.01 \%$ AsA and $0.5 \mathrm{mM}$ NBT (AsA mixture; B) or $0.01 \%$ AsA, $0.5 \mathrm{mM} \mathrm{NBT}$, and $20 \mathrm{mM}$ Tiron (Tiron mixture; C) was heated at $80^{\circ} \mathrm{C}$ for $1 \mathrm{~min}$ and $\mathrm{D}, \mathrm{E}$ and $\mathrm{F}$, respectively, were obtained. 
was measured using NBT, which is converted into a colored product in the presence of $\mathrm{O}_{2}^{-}$. There was no apparent color change in any of the 3 mixtures immediately prior to heating. On heating, the color of the control mixture barely changed (Fig. 5-D), and the AsA mixture turned purple (Fig. 5-E); the color change in the Tiron mixture (Fig. 5-F) was not as intense as that in the AsA mixture (Fig. 5-E). These results suggested that $\mathrm{O}_{2}^{-}$was generated in the reduced $11 \mathrm{~S}$ globulin concentrate during the oxidation of AsA.

Based on the results above, AsA was considered to promote the formation of SS bridges via the mechanism represented in Fig. 1-B. Therefore, we then investigated whether AsA increased the strength of the $11 \mathrm{~S}$ globulin gel when subjected to heat treatment at $80^{\circ} \mathrm{C}$.

Influence of AsA on the gelation of $11 S$ globulin For gelation, the control and the AsA mixture were prepared using the reduced $11 \mathrm{~S}$ globulin concentrate and heated at $80^{\circ} \mathrm{C}$ for 20 min; a state wherein the contents spilled over the sides of the test tube was observed after cooling with ice water (Fig. $6)$. In the control sample, the gel obtained could not retain its form when the test tube was tilted to $90^{\circ}$ (Fig. 6, image A). However, in AsA mixture, we obtained a firm gel that retained its form even when the test tube was tilted to $90^{\circ}$ (Fig. 6, image B). Catsimopoolas and Meyer (1970) reported that below a minimum concentration $(<8 \%)$, despite aggregation and increased in viscosity, gel formation does not occur. Here, although the protein content in the control and AsA mixture was $75.4 \pm 1.5(\mathrm{n}=3) \mathrm{mg} / \mathrm{ml}$, the AsA mixture yielded a rigid gel. This gel formation was considered to be due to the presence of AsA and the reduced $11 \mathrm{~S}$ globulin concentrate, which contained 17-20 thiol groups per molecule.

These results suggested that AsA increases the gel

A

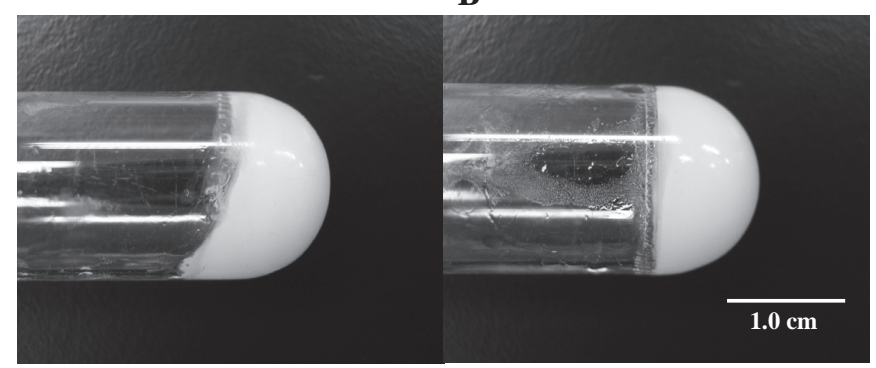

Fig. 6. Effects of AsA on the gel-forming ability of $11 \mathrm{~S}$ globulin. The control for gelation, which lacked AsA, and the AsA mixture for gelation, which contained $0.5 \%$ AsA, were heated at $80^{\circ} \mathrm{C}$ for $20 \mathrm{~min}$ to obtain the gel for each sample. After cooling the gel with ice water, the test tube was tilted to $90^{\circ}$, and the state of both gels was observed. Images A and B are the gels lacking and containing AsA, respectively. strength of $11 \mathrm{~S}$ globulin by accelerating the formation of a protein network structure via the mechanism shown in Fig. 1-B and that AsA could possibly exert beneficial effects on other food proteins containing free SH groups.

Since $11 \mathrm{~S}$ globulin reduced by 2-mercaptoethanol was used in this study, it is unclear whether AsA exerts similar effects on the native form of $11 \mathrm{~S}$ globulin due to the presence of only 2 free SH groups per molecule. Soy proteins are currently used as food additives in the heat-induced fish gel (kamaboko) industry. Although the water-absorptive capacity of soy protein powder increases the strength of heat-induced fish gel (kamaboko), it is not known to the increase the strength of gels formed by covalent bonding between myosin and soy proteins. Circle et al. (1964) reported that cysteine cleaves SS bridges; therefore, it should be possible to prepare reduced $11 \mathrm{~S}$ globulin, which contains more $\mathrm{SH}$ groups than native $11 \mathrm{~S}$ globulin, by using cysteine instead of 2-mercaptoethanol. The addition of reduced 11S globulin and AsA to raw fish paste (surimi) would result in the formation of SS bonds between the $11 \mathrm{~S}$ globulin and myosin, thus yielding a gel with higher strength. This type of reduced 11S globulin that can interact with myosin via SS bridges is currently being developed.

Acknowledgment We are grateful to Dr. Mitsutaka Kohno, Fuji Oil Co., Ltd., for providing the $11 \mathrm{~S}$ globulin powder.

\section{References}

Badley, R.A., Atkinson, D., Hauser, H., Oldani, D., Green, J.P. and Stubb, J.M. (1975). The structure, physical and chemical proteins of the soy bean protein glycinin. Biochim. Biophys. Acta, $\mathbf{4 1 2}$ 214-228.

Briggs, D.R. and Wolf, W.J. (1957). Studies on the cold-insoluble fraction of the water-extractable soybeans proteins. I. Polymerization of the 11S component through reactions of sulfhydryl groups to form disulfide bonds. Arch. Biochem. Biophys., 72, 127-172.

Catsimpoolas, N. and Meyer, E.W. (1970). Gelation phenomena of soybean globulins. 1. Protein-protein interactions. Cereal Chem., 47, 559-570.

Catsimpoolas,N., Berg, T. and Meyer, E.W. (1971) Hydrogen ion titration ionizable sidechains in native and denatured glycinin. Protein Res., 3, 63-71.

Circle, S.J., Meyer, E.W. and Whitney, R.W. (1964). Rheology of soy protein dispersions. Effect of heat and other factors on gelation. Cereal Chem., 41, 157-172.

Davies, K.J.A. (1987). Protein damage and degradation by oxygen radicals. I. General aspects. J.Biol.Chem., 262, 9895-9901.

Ellman, G.L. (1959). Tissue sulfhydryl groups. Arch. Biochem. Biophys., 82, 70-77.

Grosch, W. and Wieser, H. (1999). Redox reactions in wheat dough 
as affected by ascorbic acid. J. Cereal Sci., 29, 1-16.

Hahn, B. and Grosch, W. (1998). Distribution of glutathione in osborne fractions as affected by additions of ascorbic acid, reduced and oxidised glutathione. J. Cereal Sci., 27, 117-125.

Halliwell, B. and Gutteridge, J.M.C. (1999). Oxidative stress: Adaptation, damage, repair and death. In Free radicals in biology and medicine, $3^{\text {rd }}$ ed. Oxford University Press, New York, pp.246-350.

Ikeuchi, S., Miyamoto, Y., Katoh, T. and Nishimura, K. (2007). Action of ascorbic acid on a myosin molecule derived from carp. Biosci. Biothechnol. Biochem., 71, 2091-2094.

Kilara, A. and Harwalkar, V.R. (1996). Denaturation. In Food proteins, Properties and characterization, ed. by Nakai, S. \& Modler, H.W. Wiley-VCH, New York, pp. 71-165.

Kitamura, K., Takagi, T. and Shibasaki, K. (1976). Subunit structure of soybean 11S globulin. Agric. Biol. Chem., 40, 1837-1844.

Koehler, P. (2003). Effect of ascorbic acid in dough: Reaction of oxidized glutathione with reactive thiol groups of wheat glutelin. J. Agric. Food Chem., 51, 4954-4959.

Koshiyama, I.(1968). Chemical and physical properties of a 7S protein in soybean globulins. Cereal. Chem., 45, 394-404.

Kuninori, T. and Nishiyama, J. (1993). Recent advances in dough improvement with ascorbic acid and its derivatives. Cereal Foods World, 38, 554-559.

Laemmli, U.K. (1970). Cleavage of structural proteins during the assembly of the head of bacteriophage T4. Nature, 227, 680-685.

Lowry, O.H., Rosebrough, N.J., Farr, A.L. and Randall, R.J. (1951). Protein measurement with the folin phenol reagent. J. Biol. Chem., 193, 265-275.

Miyamoto, Y. and Nishimura, K. (2005). Generation of the thiyl radical in bovine serum albumin by the superoxide anion radical. J. Home Econ. Jpn., 56, 457-462 (in Japanese).

Miyamoto, Y. and Nishimura, K. (2006a). Beneficial effects of ascorbic acid on heat-induced fish gel (kamaboko) from the superoxide anion radical. Biosci. Biotechnol. Biochem., 70, 480-488.

Miyamoto, Y. and Nishimura, K. (2006b). Production of thiyl radical on a peptide derived from wheat protein by superoxide anion radical. Cereal Chem., 83, 472-477.

Morita, Y. (2000). Nature of soybean seed protein. In Soy protein, Korin Publishing Co., Tokyo, pp. 65-107 (in Japanese).

Nash, A.M. and Wolf, W.J. (1967). Solubility and ultracentrifugal studies on soybean globulins. Cereal Chem., 44, 183-192.

Nishimura, K., Ohishi, N., Tanaka, Y. and Sasakura, C. (1992a). Participation of radicals in polymerization by ascorbic acid of crude actomyosin from frozen surimi of Alaska Pollack during a $40^{\circ} \mathrm{C}$ incubation. Biosci. Biotechnol. Biochem., 56, 24-28.

Nishimura, K., Ohishi, N., Tanaka, Y., Ohgita, M., Takeuchi, Y., Watanabe, H., Gejima, A. and Samejima, E. (1992b). Effects of ascorbic acid on the formation process for a heat-induced gel of fish meat (kamaboko). Biosci. Biotechnol. Biochem., 56, 1737-1743.

Nishimura, K., Goto, M. and Itoh, Y. (1994). Influence of oxygen radicals produced by ascorbic acid on amino acid composition of muscle proteins during the formation of a heat-induced gel of fish meat (kamaboko). Fish. Sci., 60, 799-800.

Nishimura, K., Goto, M. and Mano, J. (1996). Participation of the superoxide radical in the beneficial effect of ascorbic acid on heat-induced fish meat gel (kamaboko). Biosci. Biotechnol. Biochem., 60, 1966-1970.

Saio, K., Kajikawa, M. and Watanabe, T. (1971). Food processing characteristics of soybean proteins. Part II. Effect of sulfhydryl groups on physical properties of Tofu-gel. Agr.Biol.Chem., 35, 890-898.

Saio, K., Sato, I. and Watanabe, T. (1974). Functional properties of heat-induced gel prepared from crude fractions of soybean $7 \mathrm{~S}$ or 11S proteins. Nippon Shokuhin Kogyo Gakkaishi, 21, 234-238 (in Japanese).

Sarwin, R., Laskawy, G. and Grosch, W. (1993). Changes in the levels of glutathione and cysteine during the mixing of doughs with L-threo- and D-erythro- ascorbic acid. Cereal Chem., 70, 553-557.

Soriani, M., Pietraforte, D., and Minetti, M. (1994). Antioxidant potential of anaerobic human plasma: Role of serum albumin and thiols as scavengers of carbon radicals. Arch.Biochem.Biophys., 312, 180-188.

Utsumi, S., Inaba, H. and Mori, T. (1981). Heterogeneity of soybean glycinin. Phytochemistry, 20, 585-589.

Wolf, W.J. and Tamura, T. (1969). Heat denaturation of soybean 11S protein. Cereal Chem., 46, 331-344.

Wolf, W.J. (1976) Purification and properties of the protein. In Soybeans, Chemistry and technology, Vol. 1, Proteins (rev), ed. by Smith, A.K. \& Circle, S.J. AVI Publishing, Westport, pp. 93-143.

Yamauchi, F. (1980). Science of food protein, The structure and the functional characteristic of soy protein. New Food Ind., 22, 26-44 (in Japanese).

Yamauchi, F. (1982). The structure and the functional characteristic of soy protein. New Food Ind., 24, 43-58 (in Japanese).

Yoshinaka, R., Shiraishi, M. and Ikeda, S. (1972). Effect of ascorbic acid on the gel formation of fish meat. Bull. Jpn. Soc. Sci. Fish., 38, 511-515. 